\title{
Paradigm Repair and Journalistic Metadiscourse
}

Media scandals often lead to scrutiny of press standards with the aim of ensuring that the malpractice does not repeat itself and the media fulfil their role in a democratic society. Such scrutiny could take the form of commissions or inquiries into press standards (see Chap. 3). For example, in the case of the NoTW phone hacking scandal, it was the Leveson Inquiry into the culture, ethics and practice of the press. These inquiries have consumed huge amount of resources (time, money, etc.) due to the important role the media play in democratic societies (see Chap. 4). Despite the amount of resources devoted to such enquiries the impact in terms of media reforms has been ominously minimal and largely ineffective (Curran and Seaton 2010). For instance, less than a decade after the Leveson Inquiry and the subsequent setting up of the Independent Press Standards Organisation (IPSO) as an improved Leveson-compliant press regulator, the press is again accused of publishing several embarrassing stories relating to the Duchess of Sussex, Meghan Markle. Such stories led to Prince Harry's so-called war against the tabloid press and Meghan's suing of the Mail on Sunday for publishing her hand-written letter to her estranged father, on the grounds of misuse of private information, infringement of copyright and breach of General Data Protection Regulation (Waterstone and Davies 2019).

This book takes the position that media reform efforts are weakened to a large extent, because of the way the media cover debates about their policy. As explained in Chap. 5, one way through which the media can

B. Ogbebor, British Media Coverage of the Press Reform Debate, https://doi.org/10.1007/978-3-030-37265-1_6 
weaken press reform efforts is by using paradigm repair strategies. Paradigm repair occurs when a press paradigm is called into question and the press refusing to examine its ways to see if there is need for change and instead chooses to protect the existing paradigm(s) through the use of different discursive strategies (Bennet et al. 1985 cited in Carlson 2015, p. 4). Based on information gathered from previous literature and my preliminary examination of news articles on the press reform debate, I identified two paradigms the press attempted to repair or protect during their coverage of the debate. They are the "press freedom" and "journalists as a crusader" paradigms. The strategies used to protect these paradigms include catastrophisation, historicisation, individualisation, self-assertion and minimisation (see Chap. 5). This chapter presents my findings on the use of the strategies of catastrophisation and historicisation. I will begin with an analysis of how catastrophisation was used in the media coverage of the press reform debate that followed the NoTW phone hacking scandal.

"Threat to the paradigm" and "threat to press freedom" are used interchangeably to talk about the press' use of the strategy of catastrophisation to protect its conceptualisation of press freedom. This strategy entails the media's use of diverse techniques to raise an alarm that the paradigm under scrutiny (in this case, press freedom) is under attack. My investigation revealed that the press functioned as two sub-interpretive spheres during their coverage of the press reform debate that arose from the NoTW phone hacking scandal and the Leveson Inquiry. Sub-interpretive spheres emerge from a situation in which journalism, rather than function as one interpretive community in its attempt to mark the boundaries of their profession (Zelizer 1993), instead functions as multiple homogeneous publics (Fraser 1992). The multiple spheres of homogeneous discourses created within a journalistic community are what I refer to as sub-interpretive spheres. Multiple sub-interpretive spheres can arise from differences and similarities in the press' interpretations of journalistic paradigms, such as press freedom, objectivity and news in the printed format. Sub-interpretive spheres may or may not be divided along the lines of media outfits because they are abstract spheres of discourses. In this book, however, the sub-interpretive spheres were divided along the lines of newspapers.

As stated earlier, I identified two sub-interpretive spheres in the media coverage of the debate that followed the NoTW phone hacking scandal and the Leveson Inquiry. One sub-interpretive sphere comprises The Sun, 
Daily Mirror, Daily Express, Daily Mail and Daily Telegraph while the other consists of the Guardian newspaper. The press reform debate was often along the lines of these two sub-interpretive spheres. This grouping does not imply that newspapers in each of the two categories agreed on every point of the press reform argument. The homogeneity of a subinterpretive sphere does not preclude disagreements on certain issues within that homogeneous public. The categorisation of the sub-interpretive spheres in this study was based on the degree of similarity in their expressions and interpretations of key points in the press reform debate, particularly their views on what constitutes press freedom. To be able to analyse these newspapers' representation of the press reform debate as subinterpretive spheres as well as individually, this book adopts a confederation pattern of analysis.

"Confederation pattern of analysis" as a pattern of critique that allows analysis of media content both in groups (e.g. of a group of newspapers) and individually (individual newspapers). This allows room for the identification of unique trends and styles within discourse. For instance, though The Sun, Daily Mirror, Daily Express, Daily Mail and Daily Telegraph all advanced a similar interpretation of press freedom, the newspapers differed in their representation of News of the World's owner Rupert Murdoch and the Press Complaint Commission, as we shall see in Chap. 8. Understanding my use of sub-interpretive spheres and the confederation pattern of analysis will enable the comprehension of my analysis of the journalistic metadiscourse, especially in relation to the grouping and individual examination of newspapers. In the next section, I discuss how the "threat to the paradigm" strategy was used in the journalistic metadiscourse on the press reform debate.

\section{Threat to the Paradigm: Press Freedom UNDER ATTACK?}

When public outrage against press "deviancy" leads to the setting up of a press commission, steps taken by such commissions to check the abuse of press freedom have often been interpreted in journalistic metadiscourse as a threat to press freedom and, by extension, a threat to democracy (Curran and Seaton 2010, pp. 327-338; Steel 2012). One of the ways through which it has done this is by using the "threat to the paradigm" or catastrophisation strategy to warn that measures designed to check abuse of press 
power were a threat to press freedom (Thomas and Finneman 2014). Table 6.1 not only affirms this argument but also shows the extent to which it was done. "Threat to press freedom" was the overall dominant theme in the journalistic metadiscourse on the debate that arose from the News of the World phone hacking scandal and the Leveson Inquiry. It was the dominant theme in 20.6 per cent of the study sample, appearing in 62.5 per cent of articles in The Sun, 35.7 per cent of Daily Express, 25.5 per cent of Daily Mirror and 18.1 per cent of Daily Telegraph (see Table 6.1). It was only surpassed in the Daily Mail by the theme "Critiquing critics of the press"; yet it still managed to exceed the Guardian's usage of the strategy, emerging in 13.3 per cent of articles in Daily Mail as against Guardian's 11.5 per cent of articles. This result reflects a trend that runs through the journalistic metadiscourse on the press reform debate, where the Guardian operated as a different interpretive community from the rest of the newspapers in my study sample, leading to my grouping of the Guardian as one sub-interpretive sphere and the rest of the press as another sub-interpretive sphere. This division of the press reform debate into two interpretive communities will become clearer as I delve deeper into the analysis of the media policy debate that arose from the News of the World phone hacking scandal and the Leveson Inquiry.

This division into two interpretive communities was also identified in the debate on the Leveson Inquiry's proposal for press regulation underpinned by statute. "Support for statutory underpinning" of a new press regulatory body was the dominant theme in the Guardian newspaper, appearing in 22.3 per cent of its sample as against 3.5 per cent in the Daily Telegraph, 1.2 per cent in the Daily Mail and zero per cent in The Sun, Daily Express and Daily Mirror (see Table 6.1). This result demonstrates that apart from the Guardian, all newspapers in my study sample advanced a discourse that was opposed to statutory regulation; this includes a regulatory body underpinned by statute. As with previous inquiries into press regulation and accountability (see Chap. 3), much of the press opposed the Leveson Inquiry's proposal for press regulation underpinned by statute. This resistance to statutory regulation accounted for arguments "against statutory underpinning" emerging as the dominant theme in 12.7 per cent of the sample for Daily Mail, 10.7 per cent for Daily Express, 9.8 per cent for Daily Mirror, 6.0 per cent for Daily Telegraph, 5.2 per cent for The Sun and 4.0 per cent for Guardian. As Curran and Seaton 
Table 6.1 Dominant theme in the study sample

\begin{tabular}{|c|c|c|c|c|c|c|c|}
\hline Dominant theme & $\begin{array}{c}\text { Guardian } \\
(\%)\end{array}$ & $\begin{array}{l}\text { Daily } \\
\text { Mail } \\
(\%)\end{array}$ & $\begin{array}{c}\text { Daily } \\
\text { Mirror } \\
(\%)\end{array}$ & $\begin{array}{l}\text { Daily } \\
\text { Telegraph } \\
\text { (\%) }\end{array}$ & $\begin{array}{l}\text { Daily } \\
\text { Express } \\
(\%)\end{array}$ & $\begin{array}{l}\text { The } \\
\text { Sun } \\
(\%)\end{array}$ & $\begin{array}{c}\text { Total } \\
(\%)\end{array}$ \\
\hline $\begin{array}{l}\text { Threat to press } \\
\text { freedom }\end{array}$ & 11.5 & 13.3 & 25.5 & 18.1 & 35.7 & 62.5 & 20.6 \\
\hline $\begin{array}{l}\text { Support for new } \\
\text { press' own } \\
\text { regulatory system }\end{array}$ & 1.5 & 4.6 & 3.9 & 2.5 & 3.6 & 4.2 & 2.9 \\
\hline $\begin{array}{l}\text { Against politicians' } \\
\text { Royal Charter }\end{array}$ & 2.8 & 4.0 & & 3.0 & & 3.1 & 2.9 \\
\hline $\begin{array}{l}\text { Against press law/ } \\
\text { statutory } \\
\text { underpinning }\end{array}$ & 4.0 & 12.7 & 9.8 & 6.0 & 10.7 & 5.2 & 6.9 \\
\hline Press achievements & 0.6 & 6.9 & 2.0 & 1.5 & 7.1 & 1.0 & 2.4 \\
\hline $\begin{array}{l}\text { Against self- } \\
\text { regulation of the } \\
\text { press }\end{array}$ & 0.9 & 0.6 & & & & & 0.5 \\
\hline $\begin{array}{l}\text { Support for } \\
\text { Leveson Inquiry }\end{array}$ & 10.5 & & 7.8 & 2.5 & 7.1 & 3.1 & 5.5 \\
\hline $\begin{array}{l}\text { Enforce existing } \\
\text { laws }\end{array}$ & & 2.3 & 3.9 & 4.5 & & & 1.7 \\
\hline $\begin{array}{l}\text { Critiquing critics of } \\
\text { the press }\end{array}$ & 0.6 & 14.5 & 2.0 & 5.0 & 3.6 & 8.3 & 5.4 \\
\hline $\begin{array}{l}\text { More dialogue } \\
\text { needed }\end{array}$ & 1.5 & & & & & & 0.6 \\
\hline Privacy & 6.2 & 9.2 & 9.8 & 11.1 & 10.7 & 3.1 & 7.9 \\
\hline $\begin{array}{l}\text { Against new press } \\
\text { regulatory system } \\
\text { formed by the press }\end{array}$ & 2.5 & & & 1.0 & & & 1.1 \\
\hline $\begin{array}{l}\text { Support for } \\
\text { politicians' Royal } \\
\text { Charter }\end{array}$ & 6.8 & 2.9 & 2.0 & 1.0 & & & 3.4 \\
\hline $\begin{array}{l}\text { Support for press } \\
\text { law/statutory } \\
\text { underpinning }\end{array}$ & 22.3 & 1.2 & & 3.5 & & & 9.3 \\
\hline $\begin{array}{l}\text { Media owners/ } \\
\text { ownership checks } \\
\text { are needed }\end{array}$ & 5.0 & 1.2 & 2.0 & 4.5 & 3.6 & 1.0 & 3.4 \\
\hline $\begin{array}{l}\text { Support for } \\
\text { self-regulation of } \\
\text { the press }\end{array}$ & 5.6 & 1.7 & 2.0 & 9.0 & 3.6 & 2.1 & 4.9 \\
\hline
\end{tabular}


Table 6.1 (continued)

\begin{tabular}{|c|c|c|c|c|c|c|c|}
\hline Dominant theme & $\begin{array}{c}\text { Guardian } \\
(\%)\end{array}$ & $\begin{array}{l}\text { Daily } \\
\text { Mail } \\
(\%)\end{array}$ & $\begin{array}{l}\text { Daily } \\
\text { Mirror } \\
(\%)\end{array}$ & $\begin{array}{c}\text { Daily } \\
\text { Telegraph } \\
\text { (\%) }\end{array}$ & $\begin{array}{l}\text { Daily } \\
\text { Express } \\
(\%)\end{array}$ & $\begin{array}{l}\text { The } \\
\text { Sun } \\
(\%)\end{array}$ & $\begin{array}{l}\text { Total } \\
(\%)\end{array}$ \\
\hline $\begin{array}{l}\text { Against Leveson } \\
\text { Inquiry }\end{array}$ & 0.6 & 8.7 & & & 3.6 & 3.1 & 2.4 \\
\hline $\begin{array}{l}\text { The politicians' } \\
\text { Royal Charter may } \\
\text { never work }\end{array}$ & 2.8 & 2.3 & 2.0 & 0.5 & & & 1.7 \\
\hline $\begin{array}{l}\text { Promoting } \\
\text { supporters of the } \\
\text { press }\end{array}$ & 0.3 & 2.9 & & & & & 0.7 \\
\hline $\begin{array}{l}\text { Promoting } \\
\text { supporters of the } \\
\text { statutory } \\
\text { underpinning } \\
\text { argument }\end{array}$ & & & & 0.5 & & & 0.1 \\
\hline $\begin{array}{l}\text { The press behaved } \\
\text { badly }\end{array}$ & 0.6 & 6.4 & 11.8 & 11.1 & & & 4.7 \\
\hline $\begin{array}{l}\text { The press is not to } \\
\text { blame }\end{array}$ & & 4.0 & 5.9 & 6.5 & & & 2.6 \\
\hline Other & 13.3 & 0.6 & 9.8 & 8.0 & 10.7 & 3.1 & 8.2 \\
\hline Total & 100.0 & 100.0 & 100.0 & 100.0 & 100.0 & 100.0 & 100.0 \\
\hline
\end{tabular}

(2010) argue, this aversion to statutory regulation by the press is largely responsible for weak reforms in press regulation.

Support for or against statutory underpinning of a new press regulatory system underpropped several arguments relating to the "threat to press freedom" theme in the journalistic metadiscourse on the press reform debate. The result reveals that "threat to press freedom" was the most prominent argument and issue of concern in the journalistic metadiscourse. The "threat to press freedom" strategy was used liberally in all newspapers in the study sample but more prominently in the subinterpretive sphere comprising of The Sun, Daily Mirror, Daily Express, Daily Mail and Daily Telegraph. Studies have shown that the opposition of the British press to statutory regulation goes beyond a commitment to protect press freedom, to a determination to control information without being accountable for its management (Curran and Seaton 2010; Petley 2013). Ensuring press accountability was one of the mandates of the Leveson (2012f). However, in its coverage of the debate that arose from 
the Inquiry, the media represented proposed measures aimed at ensuring press accountability as threats to press freedom.

Table 6.2 reveals that measures aimed at ensuring press accountability were represented as "Threat to press freedom" in 27.8 per cent of the study sample, emerging as the most frequently used interpretation of efforts at reforming the press in the journalistic metadiscourse. The measures were described as "Threat to press freedom" in 39.9 per cent of articles in The Sun, 30.8 per cent of Daily Mail, 30.3 per cent of Daily Telegraph, 28.9 per cent of Daily Express, 26.1 per cent of Daily Mirror and 20.2 per cent of Guardian (see Table 6.2). This result strengthens the finding that "threat to press freedom" was the most prominent argument advanced by the press in their coverage of the media policy debate. Table 6.2 also revealed that measures aimed at ensuring press accountability were interpreted as catastrophe for press freedom and, by extension, democracy. Proposed measures were described as "state control or

Table 6.2 Description of measures to ensure press accountability

\begin{tabular}{|c|c|c|c|c|c|c|c|}
\hline Description & $\begin{array}{c}\text { Guardian } \\
(\%)\end{array}$ & $\begin{array}{l}\text { Daily } \\
\text { Mail } \\
(\%)\end{array}$ & $\begin{array}{l}\text { Daily } \\
\text { Mirror } \\
(\%)\end{array}$ & $\begin{array}{l}\text { Daily } \\
\text { Telegraph } \\
\text { (\%) }\end{array}$ & $\begin{array}{l}\text { Daily } \\
\text { Express } \\
(\%)\end{array}$ & $\begin{array}{l}\text { The } \\
\text { Sun } \\
(\%)\end{array}$ & $\begin{array}{c}\text { Total } \\
(\%)\end{array}$ \\
\hline $\begin{array}{l}\text { Independent press } \\
\text { self-regulation }\end{array}$ & 31.1 & 6.9 & 5.8 & 7.7 & 11.1 & 8.5 & 16.8 \\
\hline $\begin{array}{l}\text { Tough press } \\
\text { regulation }\end{array}$ & 12.4 & 16.2 & 10.1 & 13.4 & 20.0 & 12.4 & 13.4 \\
\hline $\begin{array}{l}\text { Chilling effect on } \\
\text { investigative } \\
\text { journalism }\end{array}$ & 6.5 & 14.6 & 15.9 & 15.5 & 8.9 & 9.8 & 10.6 \\
\hline $\begin{array}{l}\text { Threat to press } \\
\text { freedom }\end{array}$ & 20.2 & 30.8 & 26.1 & 30.3 & 28.9 & 39.9 & 27.8 \\
\hline $\begin{array}{l}\text { State control or } \\
\text { slippery slope to } \\
\text { press licensing }\end{array}$ & 8.6 & 11.5 & 11.6 & 10.6 & 17.8 & 13.1 & 10.9 \\
\hline $\begin{array}{l}\text { Draconian or } \\
\text { punitive }\end{array}$ & 3.9 & 10.0 & 10.1 & 3.5 & 4.4 & 5.9 & 5.6 \\
\hline Retribution & 3.0 & 4.6 & 5.8 & 11.3 & 6.7 & 9.2 & 6.1 \\
\hline $\begin{array}{l}\text { Regulation that } \\
\text { delivers on } \\
\text { Leveson's } \\
\text { promises }\end{array}$ & 11.6 & 5.4 & 14.5 & 6.3 & 0.0 & 0.0 & 7.4 \\
\hline Other & 2.4 & 0.0 & 0.0 & 1.4 & 2.2 & 1.3 & 1.5 \\
\hline Total & 100.0 & 100.0 & 100.0 & 100.0 & 100.0 & 100.0 & 100.0 \\
\hline
\end{tabular}


slippery slope to press licensing" (10.9 per cent), actions that can have a "chilling effect on investigative journalism" (10.6 per cent), "retribution" against the press by corrupt politicians ( 6.1 per cent) and "draconian or punitive" (5.6 per cent). These findings demonstrate that in journalistic metadiscourse on media policy debates, the media attempt to protect existing boundaries of media policy from change by representing measures aimed at ensuring press accountability in a negative light. It can be argued that such representations contribute to the introduction of weak reforms that cannot guarantee an accountable press.

The statistical data will be better understood if we take into consideration the context within which they were used, for example, description of proposed measures as "Independent press self-regulation" (16.8 per cent), "Tough press regulation" (13.4 per cent) and "Leveson compliant" (7.4 per cent). Though the sub-interpretive sphere comprising The Sun, Daily Mirror, Daily Express, Daily Mail and Daily Telegraph gave prominence to a discourse that kicked against statutory backing of a new press regulator, they largely supported the idea of "tough" rules to check press irresponsibility (see Table 6.2). They contended that the press is capable of setting up its own regulator that would have tough rules as recommended by the Leveson Inquiry but without a statutory underpinning (Shipman 2012, p. 16). In fact, all parties in the debate including victims of the press, campaigners for victims and politicians advocated tough measures to check press misconduct. That accounted for the high frequency of the use of the word "tough" to describe measures aimed at ensuring press accountability (see Table 6.2). It was used in 20 per cent of the Daily Express, 16.2 per cent of Daily Mail, 13.4 per cent of Daily Telegraph, 12.4 per cent of Guardian, 12.4 per cent of The Sun and 10.1 per cent of Daily Mirror. "Tough press regulation" was among the top three words used to describe measures aimed at checking press behaviour (see Table 6.2). It was surpassed only by "threat to press freedom" ( 27.8 per cent) and "independent press self-regulation" (16.8 per cent).

Considering how the word "tough" was used in the journalistic metadiscourse, I am disinclined to refer to it as an evidence of catastrophisation, unlike what I thought before I embarked on the study. However, the high frequency of its usage makes it significant. The question this raises is, "does the high frequency of usage demonstrate strong commitment on the side of the press to ensure a post Leveson accountable press"? In 2016, two years from the setting up of the Independent Press Standards Organisation (IPSO), the Pilling's review commissioned by IPSO says it 
demonstrates such commitment but Hacked Off founder Brian Cathcart disagrees. In an article published in Byline.com, entitled "IPSO: The Toothless Puppet Rolls over for its masters (again)", Cathcart (2018) argues that the post-Leveson press regulator, IPSO, is far from being the "the toughest press regulator in the western world", as it claims. It can be argued that the representation of the then-proposed IPSO as "tough" during the debate was aimed at stalling the setting up of the Royal Charter on press self-regulation (see Chap. 3) or, at worse, excusing the press from signing up to a regulatory body that could perhaps make it more accountable.

Similar to how the word "tough" was used in the journalistic metadiscourse of the press reform debate, the phrase "independent press selfregulation" was not "catastrophised" (used to sound an alarm of threat to press freedom); it was used liberally by all parties in the debate to advance their proposals. They all claimed that their proposal for press reform would guarantee independent press regulation (e.g. see Wintour 2013, p. 9). The description was used more frequently in the Guardian, where it was often used to criticise the proposal for IPSO as not being independent enough to effectively check press excesses. As shown in Table 6.2, the phrase "independent press self-regulation" appeared in 31.1 per cent of the Guardian as opposed to 11.1 per cent in Daily Express, 8.5 per cent in The Sun, 7.7 per cent in Daily Telegraph, 6.9 per cent in Daily Mail and 10.1 per cent in Daily Mirror. The way "tough" and "independent press self-regulation" were used differed from my expectation before the study.

What I found was that the use of catastrophisation was limited to proposals perceived as having the potential to change the press paradigm. For instance, as Table 6.3 shows, "threat to press freedom" was the most frequently presented reason why the press should not sign up to the Royal Charter on press self-regulation. That reason was contained in 49.8 per cent of the study sample, followed by "Slippery slope to licensing of the press" (19.9 per cent). In a bid to convince readers that the press should not sign up to the Royal Charter on press regulation, much of the British press advanced the argument that "the press is able to set up [its] own regulator" (16.4 per cent), warning that [signing up to the Royal Charter] "could lead to bankruptcy of smaller newspapers" (7.6 per cent) and that there were "already too many curbs on the press" ( 5 per cent). As with the results on dominant themes, the "threat to press freedom" argument featured prominently in all newspapers in the study sample but more prominently in the sub-interpretive sphere comprising The Sun, Daily Mirror, 
Table 6.3 Reasons why the cross-party Royal Charter for press regulation should not be patronised by the press

\begin{tabular}{|c|c|}
\hline Description & Total (\%) \\
\hline Threat to press freedom & 49.8 \\
\hline Slippery slope to licensing of the press & 19.9 \\
\hline $\begin{array}{l}\text { The press is able to set up own } \\
\text { regulator }\end{array}$ & 16.4 \\
\hline $\begin{array}{l}\text { Already too many curbs on the UK } \\
\text { press }\end{array}$ & 5.0 \\
\hline $\begin{array}{l}\text { Could lead to bankruptcy of smaller } \\
\text { newspapers }\end{array}$ & 7.6 \\
\hline Other & 1.3 \\
\hline Total & 100.0 \\
\hline
\end{tabular}

Daily Express, Daily Mail and Daily Telegraph than in the Guardian newspaper, demonstrating that the strategy of "threat to the paradigm" is a major weapon used against efforts at reforming the press.

\section{Threat to the Paradigm in a Democratic Public Sphere}

This book engages with the public sphere concept both as discourse and as platform (see Chap. 4). As platform, it argues that the media ought to be a space where all parties in a debate can deliberate on issues that concern them without any form of marginalisation (Habermas 1989). The focus is not to exalt one argument or theory over another but to point out that all stakeholders in a debate should have proportionate space to advance their views on the issue in the media's public sphere. In relation to the public sphere as discourse, this book takes the position that ideas for effective media reform and its execution can emanate from media policy debates that make room for multiple spheres of homogeneous discursive publics (Fraser 1992). In this section, I begin with a discussion on the discursive publics that featured in the journalistic metadiscourse of the press reform debate, especially in relation to how these discursive publics (also referred to as sub-interpretive spheres) engaged with the threat to the paradigm strategy. As stated earlier in this chapter, I identified two discursive publics in the media coverage of the debate that arose from the News of the World phone hacking scandal and the Leveson Inquiry. The discursive public that comprised The Sun, Daily Mirror, Daily Express, 
Daily Mail and Daily Telegraph adopted a neoliberal line of argument while the second discursive public, made up of the Guardian newspaper, advanced arguments based on the theory of social democracy (see Chap. 4).

Though there were opinion articles from all newspapers in the study sample that argued against the Royal Charter on press regulation, the editorials of The Sun, Daily Mirror, Daily Express, Daily Mail and Daily Telegraph advanced the neoliberal argument that signing up to the Royal Charter on press regulation was a threat to press freedom because it was backed by statute (Dunn and Well 2012,p. 6). The Guardian newspaper argued that a statute with the power to ensure that the Royal Charter on press regulation would not be easily overturned by politicians is not the same thing as statutory regulation of the press (Toynbee 2013, p. 29). The Sun, Daily Mirror, Daily Express, Daily Mail and Daily Telegraph used the "threat to the paradigm" strategy to advance their arguments. For example, they used doom-laden phrases such as "slippery slope to the licensing of the press" (Beattie 2013, p. 26), "damage to our democracy" (McKinstry 2013, p. 14) and the loss of "300 years of press freedom" (Rayner 2012 , p. 6) to warn readers that any proposals for press regulation with statutory backing was a threat to press freedom. The Guardian newspaper denounced such warnings as a "false alarm". It did this by deconstructing the arguments made by the other newspapers. For example, where other newspapers used headlines such as "Royal Charter causes outrage as freedom of the press is cast aside after 300 years" (Brown and Little 2013 , n.p.), the Guardian countered such discourses with headlines such as "Press freedom: a tug of war, not the end of 300 years of glorious liberty" (White 2013b, n.p.). Guardian's article read:

The chorus of mostly Tory editorial writers and columnists who have been denouncing any external constraint on their right to have a good time keep claiming that Britain is facing the end of " 300 years of press freedom". Stirring stuff, but not true. Why should we believe their dire predictions for the future when they can't even be bothered to get the past right? (ibid.)

The Guardian criticised the rhetoric of "the 300 years of press freedom", describing it as one born out of the self-interest of media proprietors and their staff (White 2013a, n.p.). The Guardian's argument agrees with scholars like Curran (2013) and Allan and Jukes (2015, p. 31) who have queried the accuracy of the information that Britain has had 
approximately 300 years of press freedom. Their argument is predicated on the fact that the "taxes on knowledge" (tax on advertising, stamp duty, tax on paper) were repealed between 1853 and 1861 (see Chap. 3). This raises questions about accuracy during debates about media reform. Though all newspapers except the Guardian, regardless of their classification, advanced the warnings of threat to the paradigm, the tone of language was harsher in the tabloid and mid-market newspapers. For example, while The Sun newspaper (Kavanagh 2013, p. 8) used the headline "PM a political dwarf: sleepy, dopey, grumpy" for an editorial that condemned the then Prime Minister David Cameron's succumbing to calls for the Royal Charter on press regulation to be underpinned by statute, Daily Telegraph's editorial (Daily Telegraph 2013, p. 23) on the same issue had the headline "MPs cross the Rubicon on press regulation". The Sun's article likened David Cameron's spokesperson and the then Conservative MP for West Dorset Oliver Letwin to a "tethered goat", described the then Labour leader Ed Miliband as "geeky" and a "Marxist-born lefty", the former Prime Minister Gordon Brown as an "ex-grunt" and Hugh Grant as a "faded showbiz luvvie". Of all the newspapers, The Sun's tone of language was the most demeaning.

In line with Carlson $(2012$, p. 113) argument, perceived threats to journalism were interpreted as threats to the public. The journalistic metadiscourse of all the newspapers except the Guardian was often constructed to portray the public as the victim of any form of statutory intervention in press regulation. Linguistic devices such as hyperboles, "you-centeredness" (direct address), sensational vocabulary and powerful imagery were employed to make the reader visualise the press as the crusader and the public as victims, while politicians, victims of press abuse and campaigners for such victims appear as villains. For example, an article in the Daily Mail captioned "A rotten day for freedom" stated:

They want to ordain how we run your newspapers. They'll be coming after you next, mes braves. Thou shalt not think impure thoughts. Thou shalt conform and applaud the Westminster elite. All hail to The System. All must subscribe to egalitarianism. All must suppress their inner eruptions. Control, control: This is the impetus. (Letts 2013, n.p.)

In this article, the linguistic device of "you-centeredness" as described by Fairclough (1995, cited in Marston 2002, p. 86) was used to persuade the reader to see politicians, victims of press abuse and campaigners for 
such victims as their enemies. This interpretation runs contrary to Lord Justice Leveson's claim (Leveson 2012, pp. 14-15) that his proposal of a statutorily backed press regulatory body would protect the members of the public from press abuse. As with Putnis' (2000, pp. 106-110) analysis of newspaper coverage of the media policy debate in Australia, echoes from George Orwell's 1984 were used to strengthen arguments against statutorily backed press regulation (e.g. see Beattie 2013). The Daily Express wrote:

In practice, statutory regulation would mean government censorship. Our reading matter would be vetted by official bureaucrats, accountable not to the public but to the politicians, Whitehall and probably even the European courts. We would soon be sliding down the road towards Orwell's Ministry of Truth, the sinister organisation that directed the press in the novel 1984. (McKinstry 2012, p. 14)

Similarly, in its comments section, Daily Mail stated: "But today MPs must put such petty bitterness aside. Labour and the Lib Dems should remember they are the heirs of Hardie, Orwell and John Stuart Mill-true giants in the fight for freedom and democracy" (Daily Mail 2013a, n.p.). These quotations also reveal the press" use of the "us" and "them" contrast (Marston 2002, p. 86) to position the reader on the side of the press, thus creating an in-group (using "We" and "Our") with the policymakers as the outsiders and potential enemy.

Again, the Guardian countered the other newspapers' interpretations of statutorily backed press regulation including their use of echoes from George Orwell's 1984 and other scholars, as can be seen in these statements:

The Guardian, FT and Independent agreed with the parliamentary route [statutory underpinning]. It is unclear why Milton, Wilkes or Orwell would be happy to bequeath freedom of expression to the government of the day. (Rusbridger 2013, p. 26)

The public rightly snort in derision at high-flown cant about press freedom while scoundrels brandish quotes from Milton and Orwell as cover to let them bully as they please. (Toynbee 2013, p. 29)

All newspapers except the Guardian used hyperbolic comparisons to advance the argument that a statutorily backed regulatory body would make Britain a totalitarian regime like Russia, China, Iran, Venezuela, 
Zimbabwe and Saudi Arabia, and warned that even such regimes are appalled by Britain's decision (Johnson 2012, pp. 10-11). A Daily Mail headline read, "How even the Kremlin and Iran scorn Britain for shackling a free press - from New York to Sydney, the world condemns appalling and unimaginable gag on liberty" (Daily Mail 2013b), and an article written by the then Mayor of London, Boris Johnson, for the Daily Telegraph stated:

All my life I have thought of Britain as a free country, a place that can look around the world with a certain moral self-confidence. How can we wag our fingers at Putin's Russia, when we are about to propose exemplary and crippling fines on publications that do not sign up to the regulatory body? How could we have criticised the Venezuela of Hugo Chavez? (Johnson 2013, p. 24)

The Guardian newspaper also contested these warnings as can be seen in this example:

Then there was The Sun's claim that, if the press were subject to statutory regulation, Britain would, like Russia, Zimbabwe and Iran, have "state stooges ... deciding what can or can't be printed in your Sun". It quoted a YouGov poll showing $75 \%$ of Britons thought that, under press regulation set up by parliament, there was "a risk" that politicians would try to stop newspapers criticising them. It neglected to mention that $63 \%$ did not trust the industry to set up "a fair system of press regulation". The Mail's Richard Littlejohn argued—or, rather, screamed — that statutory regulation would lead to journalists who exposed tax avoiders being jailed. (Wilby 2012, p. 30)

This warning by the neoliberal press of a "threat to press freedom" if press regulation is underpinned by statute also surfaced during descriptions of the Leveson Inquiry in the journalistic metadiscourse on the press reform debate. Table 6.4 shows that the Leveson Inquiry was described as a threat to press freedom in 27.1 per cent of the study sample: in 38.0 per cent of The Sun newspaper's, 33.3 per cent of Daily Express', 28.2 per cent of Daily Mirror's, 28.6 per cent of Daily Telegraph's, 28.9 per cent of Daily Mail's and 20.5 per cent of Guardian's descriptions of the Leveson Inquiry. The threat to press freedom argument came behind "solution to efforts at curbing press excesses" which emerged in 28.4 per cent of the study sample (see Table 6.4). It appeared in 48.9 per cent of the Guardian newspaper, 20.5 per cent of Daily Mirror, 16.7 per cent of Daily Express, 
Table 6.4 Description of Leveson Inquiry

\begin{tabular}{lrrrrrrr}
\hline Description & $\begin{array}{c}\text { Guardian } \\
(\%)\end{array}$ & $\begin{array}{c}\text { Daily } \\
\text { Mail } \\
(\%)\end{array}$ & $\begin{array}{c}\text { Daily } \\
\text { Mirror } \\
(\%)\end{array}$ & $\begin{array}{c}\text { Daily } \\
\text { Telegraph } \\
(\%)\end{array}$ & $\begin{array}{r}\text { Daily } \\
\text { Express } \\
(\%)\end{array}$ & $\begin{array}{r}\text { The } \\
\text { Sun } \\
(\%)\end{array}$ & $\begin{array}{c}\text { Total } \\
(\%)\end{array}$ \\
\hline $\begin{array}{l}\text { A threat to press } \\
\text { freedom }\end{array}$ & 20.5 & 28.9 & 28.2 & 28.6 & 33.3 & 38.0 & 27.1 \\
$\begin{array}{l}\text { Harmful to UK's } \\
\text { reputation }\end{array}$ & 2.3 & 3.9 & 5.1 & 7.8 & 5.6 & 12.0 & 5.4 \\
$\begin{array}{l}\text { A chilling effect } \\
\text { on journalism }\end{array}$ & 8.7 & 17.1 & 20.5 & 26.0 & 22.2 & 15.2 & 15.0 \\
$\begin{array}{l}\text { A fair deal } \\
\begin{array}{l}\text { Solution to } \\
\text { efforts at curbing }\end{array}\end{array}$ & 12.8 & 3.9 & 2.6 & 11.7 & 0.0 & 0.0 & 7.9 \\
press excesses & & 15.8 & 20.5 & 13.0 & 16.7 & 8.7 & 28.4 \\
$\begin{array}{l}\text { Illegitimate/ } \\
\text { unfair to the press }\end{array}$ & 0.5 & 18.4 & 10.3 & 3.9 & 5.6 & 15.2 & 7.1 \\
$\begin{array}{l}\text { Anti-democratic } \\
\text { Other }\end{array}$ & 3.7 & 9.2 & 10.3 & 7.8 & 16.7 & 9.8 & 7.1 \\
Total & 2.7 & 2.6 & 2.6 & 1.3 & 0.0 & 1.1 & 2.1 \\
\hline & 100.0 & 100.0 & 100.0 & 100.0 & 100.0 & 100.0 & 100.0 \\
\hline
\end{tabular}

15.8 per cent of Daily Mail, 13 per cent of Daily Telegraph and 8.7 per cent of The Sun.

While it is expected that Guardian would have a high percentage of references to the Leveson Inquiry as a "solution to efforts at curbing press excesses" due to its preferred interpretation of press freedom which is in step with much of Leveson's proposals, the high percentage of references to Leveson Inquiry as a "solution to efforts at curbing press excesses" by the other newspapers looks contradictory on face value. An exploration of the context within which those references were made, however, showed that the press, apart from the Guardian, in an effort to promote their then proposed self-regulatory body, the Independent Press Standards Organisation (IPSO), described it as Leveson compliant and, as such, a solution to efforts at curbing press excesses. This accounted for the seemingly contradictory data of the Leveson Inquiry being described as both a threat to press freedom (27.1 per cent) and a solution to efforts at curbing press excesses (28.4 per cent) in Table 6.4.

In sum, the neoliberal concept of press freedom featured in the debate as a paradigm which the commercial press fought hard to protect rather than scrutinise to see if there is need for change or modification. The fact that Guardian newspaper challenged the neoliberal perspective shows that 
the press does not always function as one interpretive community (Zelizer 1993) when it goes about maintaining the boundaries of its profession. As stated earlier in this chapter, the press functioned as two homogeneous publics (sub-interpretive spheres) during their coverage of the media reform debate. While multiple spheres of homogeneous publics are closer to the democratic ideal as argued by Fraser (1992, p. 129), the problem here is that the bulk of the press (five out of six newspapers in the study sample) advanced the neoliberal perspective as compared to one (Guardian) which advanced a social democratic view. While the Guardian had a high volume of coverage of 323 out of 870 news articles on the debate, all of its stories only reached its print readership of 4.06 million between 2011 and 2012 (readership figures for April 2011 to March 2012, NRS PADD 2012). Even with its combined print and online readership of about 9 million, the reach of Guardian is beaten by the combined readership of the six newspapers: 20.5 million print and 49.4 million combined print and online readership (readership figures for April 2011 to March 2012, NRS PADD 2012). This shows the imbalance in the potential power of influence between the neoliberal and the social democratic press.

The danger this poses to democracy is that propagators of the neoliberal perspective have an unfair advantage over the propagators of other views because their perspective reaches the bulk of the print readership including policymakers. This promotes inequality between arguments that could advance the "freedoms of the media" and arguments that could protect the "freedoms of the public". This does not reflect a democratic public sphere. The implication is that because the newspapers in this subinterpretive sphere that advanced a neoliberal discourse are commercial and, therefore, market driven, any reform with a capacity to inhibit the commodification of news, even when it can effectively check malpractice, was represented in much of the news as a threat to press freedom. As stated in the introductory chapter, one of the aims of this book is to show how the media cover debates about their policy and the implication for their manner of coverage for media reform efforts and democracy at large. Having examined how the strategy of "threat to the paradigm" was used in the coverage of the media reform debate, the following section discusses how the strategy of historicisation was used in the debate. 


\section{HistoricisATION}

Historicisation refers to the use of history to strengthen contemporary arguments (see Chap. 5). At first glance, it appeared as if within the journalistic metadiscourse on the press reform debate, the strategy of historicisation was used to relay media self-critique and demonstrate remorse for press misconduct. However, a closer look into the journalistic metadiscourse revealed that the strategy was mainly used for dramatic effects; to strengthen arguments for or against statutory underpinning of a new press regulatory body, and to argue that the present-day British press is better than those of the past. First, historicisation was used to emphasise that the press got it wrong in the NoTW phone hacking scandal. All parties in the debate including the press, victims of the press, victims' campaigners, the Leveson Inquiry and politicians accepted that the press had behaved badly with respect to the phone hacking (e.g. see Moore 2011).

Table 6.5 shows that the top three descriptions of the phone hacking in the journalistic metadiscourse were "Bad journalism/irresponsible" (40 per cent), "Criminality" (33.2 per cent) and "Less serious than portrayed"

Table 6.5 Description of phone hacking

\begin{tabular}{|c|c|c|c|c|c|c|c|}
\hline $\begin{array}{l}\text { Description of } \\
\text { phone hacking }\end{array}$ & $\begin{array}{c}\text { Guardian } \\
(\%)\end{array}$ & $\begin{array}{l}\text { Daily } \\
\text { Mail } \\
(\%)\end{array}$ & $\begin{array}{l}\text { Daily } \\
\text { Mirror } \\
(\%)\end{array}$ & $\begin{array}{l}\text { Daily } \\
\text { Telegraph } \\
\text { (\%) }\end{array}$ & $\begin{array}{c}\text { Daily } \\
\text { Express } \\
(\%)\end{array}$ & $\begin{array}{l}\text { The } \\
\text { Sun } \\
(\%)\end{array}$ & $\begin{array}{c}\text { Total } \\
(\%)\end{array}$ \\
\hline Unavoidable & 0.8 & 2.3 & 4.4 & 1.7 & 0.0 & 2.9 & 1.9 \\
\hline $\begin{array}{l}\text { The work of a few } \\
\text { bad apples in } \\
\text { journalism }\end{array}$ & 10.6 & 3.5 & 6.7 & 4.2 & 16.7 & 25.7 & 8.5 \\
\hline Anti-democratic & 4.1 & 1.2 & 4.4 & 0.0 & 0.0 & 2.9 & 2.1 \\
\hline $\begin{array}{l}\text { Bad journalism/ } \\
\text { irresponsible }\end{array}$ & 43.1 & 39.5 & 46.7 & 38.1 & 50.0 & 22.9 & 40.0 \\
\hline $\begin{array}{l}\text { It is not new to } \\
\text { journalism }\end{array}$ & 1.6 & 0.0 & 2.2 & 3.4 & 0.0 & 0.0 & 1.6 \\
\hline $\begin{array}{l}\text { Less serious than } \\
\text { portrayed }\end{array}$ & 21.1 & 4.7 & 0.0 & 0.0 & 0.0 & 22.9 & 8.9 \\
\hline Criminality & 17.9 & 44.2 & 28.9 & 45.8 & 33.3 & 22.9 & 33.2 \\
\hline $\begin{array}{l}\text { Demonstrates the } \\
\text { importance of a } \\
\text { free press }\end{array}$ & 0.0 & 4.7 & 6.7 & 5.9 & 0.0 & 0.0 & 3.3 \\
\hline Other & 0.8 & 0.0 & 0.0 & 0.8 & 0.0 & 0.0 & 0.5 \\
\hline Total & 100.0 & 100.0 & 100.0 & 100.0 & 100.0 & 100.0 & 100.0 \\
\hline
\end{tabular}


(8.9 per cent). The least used among the codes provided was "It is not new to journalism" which was used in only 1.6 per cent of the study sample. Others were "The work of a few bad apples in journalism" (8.5 per cent); "Demonstrates the importance of a free press" (3.3 per cent); "Antidemocratic" (2.1 per cent); "Unavoidable" (1.9 per cent) and "Other" ( 0.5 per cent) (see Table 6.5). Most of these variables will be expatiated in Chap. 8. At this stage, it will suffice to point out that these results reveal a high frequency of condemnation of the phone hacking scandal and other acts of press misconduct in the journalistic metadiscourse.

This acknowledgement of wrongdoing by the press via the strategy of historicisation may or may not be for the purpose of self-critique. It can be argued that historicisation was used for infotainment rather than selfcritique. My investigation revealed that all six newspapers in the study sample employed historicisation to affirm press bad behaviour and the narrative was often entertaining (e.g. see Sabbagh 2011, p. 19). The reasons could be to boost readership or could just be a subconscious urge to entertain readers. This affirms the argument that journalists often exaggerate dramatic elements in stories in order to enhance their newsworthiness (Galtung and Ruge 1965, cited in Frost 2007; Hall et al. 1978, cited in Allan 2010). It also agrees with Stiegler's (2013, p. 137) assertion that during the coverage of media policy debates, the press use negative stories as infotainment.

An example is an article by the Guardian newspaper headline "what journalistic 'operators' got up to in the past", an excerpt from Keeble and Mair's book The Phone Hacking Scandal: Journalism on Trial (Greenslade 2012 , n.p.). While acknowledging press bad behaviour, the article highlighted the "scoop-getting exploits" of journalists in the 1950s-1960s which included "composing quotable quotes because interviewees were often inarticulate or tongue-tied"; "impersonating a pop group manager in a telephone call in order to trap an impresario suspected of taking backhanders when booking bands"; obtaining pictures from a police accomplice of a house on fire in which an elderly former actress died and using the "services of an "earwigger", a person employed to listen in to police radio calls which was arguably an illegal activity" (ibid).

Another way historicisation was used in the coverage of the press reform debate, outside acknowledging bad behaviour, was to argue that the present-day press is better than the press of yesteryear. For some, it was used to argue that phone hacking is not new in the sense of subterfuge being used for news stories. It was also used to call attention to the need 
to check the concentration of media ownership. For instance, the example from the Guardian, "what journalistic 'operators' got up to in the past" (Greenslade 2012, n.p.), not only acknowledged press excesses through historicisation but also used the strategy to affirm that the present-day press is, to a large extent, better than that of the past as well as to call attention to the problem of concentration of media ownership. Though there was wide acknowledgement of press misconduct in the journalistic metadiscourse, a study of the context within which this was expressed showed that the underlying reason for such acknowledgement of wrong was often in defence of the press. This explains why despite the fact that 40 per cent of the study sample described phone hacking as bad and irresponsible journalism, this view emerged as a dominant theme (under the name "the press behaved badly") in only 4.7 per cent of the study sample (see Table 6.1).

Historicisation was also used to strengthen arguments for and against press reform. All newspapers examined except Guardian used historicisation to argue against press reform, particularly against the statutory underpinning of a new press regulatory body. For example, in a bid to convince readers that statutory regulation is not synonymous with good press behaviour, the Daily Mail, in an article headlined "Kate's right to be angry. But only King Canute would think privacy laws can hold back this tide" argued that the French press despite being bound by constitutional right to privacy printed topless pictures of the Duchess of Cambridge taken through clandestine means while the British press refrained from doing so. The story which used historicisation to argue that the British press has improved since the death of princess Diana concluded by saying that "the best protection against violation of privacy is self-regulation".

On the other hand, the Guardian used historicisation to strengthen arguments in support of a statutorily backed press regulatory body (Robinson et al. 2011, p. 1). While stressing the need for reform, a report by the Guardian entitled "Leveson inquiry: Analysis: Calls for new laws after evidence that puts the out-of-control paparazzi in the frame" stated:

It was as if nothing had changed in the years since The Sun, the News of the World and Hello! announced they had stopped using paparazzi pictures of Kate Middleton after she was mobbed outside her house at the time of her 25th birthday in 2007—or, of course, since Diana died trying to evade the photographers at high speed in Paris in 1997. (Sabbagh 2011, p. 19) 
Each sub-interpretive sphere (Guardian as one interpretive sphere and the other five newspapers as another) used the strategy of historicisation to buttress their stance for or against statutory underpinning of press regulation. This divide in interpretation runs through much of the journalistic metadiscourse on the press reform debate that arose from the News of the World phone hacking scandal and the Leveson Inquiry, defying newspaper class divisions. A force stronger than newspaper classification shaped the debate and that force needs to be investigated to see that it does not rob the press of its autonomy to function as a democratic public sphere. If the force is commercialism, then arguments for plurality of media ownership would need to go beyond concentration of ownership to plurality of business models because different patterns of funding appear to produce differences in interpretations. The issue of media ownership and its possible impact on journalistic metacoverage will be examined in greater detail in Chap. 8 .

\section{Conclusion}

Using statistical data, this chapter showed how the strategies of "threat to the paradigm" and "historicisation" were used in the coverage of the debate that arose from the NoTW phone hacking scandal and the Leveson Inquiry. The strategy of historicisation was used to acknowledge press bad behaviour while serving more as an element of drama in the journalistic metadiscourse. This affirms the argument of scholars who assert that debates are often presented as infotainment and with an element of drama, for the purpose of entertaining readers and boosting sales (Galtung and Ruge 1965, cited in Harcup and O'Neill 2010). Infotainment, depending on how it is used, can be detrimental to democracy. It can lead to the dumbing down of news and make readers a consumer audience whose appetite is assuaged by such coverage, distracting them from active participation in efforts at reforming the press.

Historicisation was also used to back up arguments that the present-day press is better behaved than the press of the 1950s and 1960s. The Sun, Daily Mirror, Daily Express, Daily Mail and Daily Telegraph used the strategy to argue against press reform, thus protecting their conceptualisation of a free press. The Guardian used the strategy to support press reforms, challenging the other papers' neoliberal interpretation of press freedom. Historicisation did not feature as a dominant paradigm repair strategy in the journalistic metadiscourse on the press reform debate. "Threat to the [press freedom] paradigm" was the most prominent 
strategy used in the coverage. It featured more prominently in The Sun, Daily Mirror, Daily Express, Daily Mail and Daily Telegraph newspapers.

These newspapers used the strategies of "historicisation" and "threat to the paradigm" to protect the neoliberal concept of press freedom. Using diverse linguistic devices including hyperboles, "you-centeredness", adjectives and doom-laden rhetoric, they warned that statutory underpinning of a press regulator was a slippery slope to licensing of the press and, as such, a threat to press freedom. Using the sustenance of democracy as their defence, they kicked against statutory underpinning of a new press regulatory body warning that a press regulatory body underpinned by statute would harm the reputation of the UK. My investigation revealed that their interpretation of press freedom was hegemonic in the journalistic discourse on the press reform debate because much of the British press advanced this argument.

Though it can be argued that the Guardian served as an alternative public in the debate, the Guardian was one out of six national newspapers. There are also questions about whether the Guardian's counterdiscourse was in the public interest or was for the protection of its image as a crusader (for more on the crusader image see Chap. 8), as the medium through which the extent of the scandal came to light. This question became more pertinent because of Guardian's failure to sign up to the regulatory body underpinned by statute (the Royal Charter on press regulation), the same body it had encouraged other press organisations to embrace. The Guardian's decision to support the cancellation of the second part of the Leveson Inquiry in 2018 (Guardian 2018) also adds weight to that suspicion.

It is important for consumers of media coverage of debates about their policy to become aware of the ideologies behind the representations and the strategies used to advance the various arguments. "Threat to the paradigm" and "historicisation" are part of that knowledge needed to fully comprehend journalistic metadiscourse on media policy debates. An understanding of the way the media cover debates about their policy will help the public digest the coverage of debates on media policy intelligently and push for healthy and effective media reform. Having examined how the media used the strategy of "threat to the paradigm" and historicisation" in this chapter, the following chapter will show how attributions of blame for the scandal were represented in the journalistic metadiscourse. It will also reveal how the strategies of individualisation, self-assertion and minimisation were utilised in press coverage of the debate. 


\section{REFERENCES}

Allan, S. (2010). News culture: Issues in cultural and media studies (3rd ed.). Maidenhead: Open University Press.

Allan, S., \& Jukes, S. (2015). Guarding the guardians: The leveson inquiry and the future of independent journalism. In J. Bennett \& N. Strange (Eds.), Media independence: Working with freedom or working for free? London: Routledge.

Beattie, J. (2013). Revenge of the politicians; day UK press was shackled PM Cameron bows to pressure \& paves way for a 'ministry of truth'. Daily Mirror, March 19, p. 26.

Brown, M., \& Little, A. (2013). Royal Charter causes outrage as freedom of press is cast aside after 300 years. Daily Express, October 31.

Carlson, M. (2012). On the condition of anonymity: Unnamed sources and the battle for journalism. Illinois: University of Illinois Press.

Carlson, M. (2015). Metajournalistic discourse and the meanings of journalism: Definitional control, boundary work, and legitimation. Communication Theory, 26(4), 349-368.

Cathcart, B. 2018. Select committee savages IPSO for failing to protect Muslims [Online]. ByLine. Available at. https://www.byline.com/column/68/article/2059. Accessed 13 Aug 2019.

Curran, J. (2013). Letter: Press freedom canard. Guardian, November 6.

Curran, J., \& Seaton, J. (2010). Power without responsibility: Press, broadcasting and the internet in Britain (7th ed.). London: Routledge.

Daily Mail. (2013a). Don't sacrifice our hard-won freedoms. March 18.

Daily Mail. (2013b). How even the Kremlin and Iran scorn Britain for shackling a free press. March 21.

Daily Telegraph. (2013). MPs cross the Rubicon on press regulation. March 19 , p. 23.

Dunn, N. T., \& Well, T. (2012). State-run watchdog 'will gag free press'; 75\% of brits see threat to papers. The Sun, November 15, p. 6.

Fraser, N. (1992). Rethinking the public sphere: A contribution to the critique of actually existing democracy. In C. Calhoun (Ed.), Habermas and the public sphere (pp. 109-142). London: MIT Press.

Frost, C. (2007). Journalism ethics and regulation (2nd ed.). Essex: Pearson Education Limited.

Greenslade, R. (2012). Hacking book: What journalistic 'operators' got up to in the past. Guardian, September 3.

Guardian. (2018). The Guardian view on Leveson part two: Look ahead, not behind [Online]. Guardian, March 1. Retrieved January 15, 2019, from https://www.theguardian.com/commentisfree/2018/mar/0l/ the-guardian-view-on-leveson-part-two-look-ahead-not-behind.

Habermas, J. (1989). The structural transformation of the public sphere: An inquiry into a category of bourgeois society. Cambridge: Polity Press. 
Harcup, T., \& O’Neill, D. (2010). What is news? Galtung and Ruge revisited. Journalism Studies, 2(2), 261-280.

Johnson, B. (2012). It's one of the glories of this country that we have free, exuberant media. They keep public life much cleaner \& that makes Britain a wonderful place to live. The Sun, November 29, pp. 10-11.

Johnson, B. (2013). Only a gutter press can keep clean the gutters of public life; Legislation to control newspapers threatens our global reputation for honest dealing. Daily Telegraph, March 18, p. 24.

Kavanagh, T. (2013). PM a political dwarf: Sleepy, dopey, grumpy. The Sun, March 25 , p. 8.

Letts, Q. (2013). Thou shalt conform and hail the Westminster elite. Daily Mail, October 9.

Leveson, B. (2012). An inquiry into the culture, practices and ethics of the press: executive summary [Online]. Available at: https://www.gov.uk/government/ uploads/system/uploads/attachment_data/file/229039/0779.pdf. Accessed 27 Dec 2016.

Leveson, B. 2012f. An inquiry into the culture, practices and ethics of the press: executive summary [Online]. Available at: https://www.gov.uk/government/ uploads/system/uploads/attachment_data/file/229039/0779.pdf [Accessed: 27 December 2016]

Marston, G. (2002). Critical discourse analysis and policy-orientated housing research. Housing, Theory and Society, 19(2), 82-91. Online.

McKinstry, L. (2012). A free press is at the very heart of British democracy. Daily Express, November 29, p. 14.

McKinstry, L. (2013). Legal aid is now a racket that only benefits lawyers. Daily Express, June 6, p. 14.

Moore, J. (2011). Do you want state telling us what we can tell you? Sun, November 23, p. 13.

NRS PADD. (2012). NRS print and digital data survey [Online].. Available at: https://www.theguardian.com/news/datablog/2012/sep/12/digital-newspaperreaderships-national-survey\#quality. Accessed 14 Jan 2017.

Petley, J. (2013). Public interest or public shaming? In J. Petley (Ed.), Media and public shaming: Drawing the boundaries of disclosure (pp. 19-42). London: I.B. Tarius.

Putnis, P. (2000). Newspapers as political instruments in media policy debate. Agenda: A Journal of Policy Analysis and Reform, 7(2), 99-112.

Rayner, G. (2012). Don't let newspaper victims set the rules, PM is warned. Daily Telegraph, November 29, p. 6.

Robinson, J., et al. (2011). Press standards: Press regulation: Newspapers cannot be trusted, says Guardian man who broke hacking story. Guardian, November 30, p. 16.

Rusbridger, A. (2013). We need reform and a free press. This will require both time and openness. Guardian, March 25, p. 26. 
Sabbagh, D. (2011). Calls for new laws after evidence that puts the out-of-control paparazzi in the frame. Guardian, November 26, p. 19.

Shipman, T. 2012. Law to regulate the press could be abused, warns PM. Daily Mail, December 11, p.14.

Steel, J. (2012). Journalism and free speech. London: Routledge.

Stiegler, Z. (2013). Regulating the web: Network neutrality and the fate of the open internet. Plymouth: Rowman \& Littlefield.

Thomas, R. J., \& Finneman, T. (2014). Who watches the watchdog? Journalism Studies, 15(2), 172-186.

Toynbee, P. (2013). Will the press repent its nasty ways? Don't hold your breath. Guardian, March 19, p. 29.

Waterstone, J., \& Davies, C. (2019). Meghan sues Mail on Sunday as Prince Harry launches attack on tabloid press [Online]. Guardian, October 2. Retrieved January 12, 2020, from http://www.theguardian.com/uk-news/2019/ oct $/ 01 /$ meghan-sues-mail-on-sunday-for-publishing-letter-to-her-father.

White, M. (2013a). Press regulation who has won? Guardian, March 18.

White, M. (2013b). Press freedom: A tug of war, not the end of 300 years of glorious liberty. Guardian, March 28.

Wilby, P. (2012). Cameron's dilemma: The press can still ruin careers: Coverage of the Leveson Inquiry proves why the press must be reformed, but also shows the risk involved in doing so. Guardian, November 27, p. 30.

Wintour, P. (2013). Press regulation: Royal charter sealed after legal action fails: court rejects newspapers' attempt to block measure: Publishers will set up rival independent regulator. Guardian, 31 October, p.9.

Zelizer, B. (1993). Journalists as interpretive communities. Critical Studies in Mass Communication, 10, 219-237.

Open Access This chapter is licensed under the terms of the Creative Commons Attribution 4.0 International License (http://creativecommons.org/licenses/ by $/ 4.0 /$ ), which permits use, sharing, adaptation, distribution and reproduction in any medium or format, as long as you give appropriate credit to the original author(s) and the source, provide a link to the Creative Commons licence and indicate if changes were made.

The images or other third party material in this chapter are included in the chapter's Creative Commons licence, unless indicated otherwise in a credit line to the material. If material is not included in the chapter's Creative Commons licence and your intended use is not permitted by statutory regulation or exceeds the permitted use, you will need to obtain permission directly from the copyright holder.

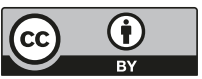

